\title{
FUNKCIONALNA PISMENOST VOZNIKOV OSEBNIH VOZIL
}

\section{Resnični zapisi v prijavah nezgod zavarovalnici}

Pogosto smo v dilemi, kadar hočemo opredeliti pojem funkcionalna pismenost ali nepismenost. V strokovnih besedilih se skušamo izogniti zlasti pojmu nepismenost, ki ni najbolj posrečen in seveda tudi ne dovolj jasen.

Primeri, ki jih želim predstaviti v tem prispevku, pa tak izraz kar potrjujejo ali upravičujejo; to moramo, ko preberemo navedene zapise, priznati. Gre za to, da oseba, ki mogoče nekoliko slabše miselno in čustveno deluje zaradi šoka, preživetega ob nezgodi, ne zna zapisati, kar je hotela izraziti; morda bi to bolje povedala, kot je znala zapisati.

Več v tem prispevku nisem nameraval komentirati. Najprepričljivejši so navedeni primeri sami. Ob njih se lahko tudi od srca nasmejimo. Navedel bom 23 resničnih izjav, napisanih na obrazce za prijavo nezgode zavarovalnici.

1. Ko sem prišla domov, sem zapeljala na dvorišče napačne hiše in se zabila v drevo, ki ga doma nimamo.

2. Drugi avto se je zaletel $v$ mojega, ne da bi me prej opozoril.

3. Mislil sem, da je bilo okno spuščeno, ampak sem opazil, da je bilo dvignjeno, ko sem dal skozenj mojo glavo.

4. Zaletel sem se v parkiran kamion, ki je prihajal z druge strani.
5. Kamion se je zabil skozi moje stransko okno v obraz moje žene.

6. Pešec se je zaletel vame in se spravil pod moj avto.

7. Neki tip je bil povsod po cesti in sem moral večkrat obrniti volan, preden sem ga zadel.

8. Odpeljal sem na rob ceste, počistil svojo taščo in se odpravil do naslednje postaje, peš.

9. Poskusil sem ubiti muho in sem odpeljal $\mathrm{v}$ drog telefona.

10. Ves dan sem nakupovala rastline in sem bila na poti domov. Ko sem prišla do križišča, je en grm padel predme in nisem videla drugega avtomobila.

11. Vozil sem 40 let, ko sem zaspal za volanom in imel eno nesrečo.

12. Bila sem na poti $k$ doktorju zaradi zadnjičnih problemov. Moje umetno koleno je popustilo in sem imela nesrečo.

13. Ko sem prišel do križišča, se je tam nenadno prikazal znak, ki se ni še nikoli prej prikazal tam. Nisem se mogel ustaviti, zato sem imel nesrečo.

14. Da se ne bi zabil v odbijač avtomobila pred mano, sem zadel pešca.

15. Moj avtomobil je bil pravilno parkiran, ko je zadel v drugo vozilo. 
16. Nevidni avtomobil je pripeljal od nikoder, zadel moj avto in izginil.

17. Policiji sem povedal, da nisem bil poškodovan. Vendar sem, ko sem snel klobuk, opazil, da je moja lobanja počena.

18. Prepričan sem bil, da starec ne bo nikoli prišel na drugo stran ceste, ko sem zadel vanj.

19. Pešec ni vedel, v katero smer naj steče, zato sem zapeljala čezenj.

20. Videla sem počasno premikajočega se, žalostnega starega gospoda, ko se je odbil od pokrova mojega avtomobila.

21. Posreden razlog nesreče je bil majhen tip $\mathrm{v}$ majhnem avtomobilu $\mathrm{z}$ velikimi usti.

22. Vrglo me je iz avtomobila, ko je ta zapustil cesto. Našlo me je nekaj psov v bližnjih smetnjakih.

23. Telefonski drog se je približeval. Skušala sem se mu odmakniti, ko je nenadno zadel v sprednji del mojega avtomobila.

dr. Zoran Jelenc 